Article

\title{
Quality Attributes of Cryoconcentrated Calafate (Berberis microphylla) Juice during Refrigerated Storage
}

\author{
Patricio Orellana-Palma ${ }^{1, * \mathbb{C}}$, Guisella Tobar-Bolaños ${ }^{2,3}$, Nidia Casas-Forero ${ }^{2,4} \mathbb{( \mathbb { D }}$, \\ Rommy N. Zúñiga ${ }^{1,5}\left(\mathbb{D}\right.$ and Guillermo Petzold ${ }^{2}(\mathbb{D})$ \\ 1 Department of Biotechnology, Universidad Tecnológica Metropolitana, Las Palmeras 3360, P.O. Box, \\ 7800003 Nuñoa, Santiago, Chile; rommy.zuniga@utem.cl \\ 2 Laboratory of Cryoconcentration, Department of Food Engineering, Universidad del Bío-Bío, \\ Av. Andrés Bello 720, Casilla 447, 3780000 Chillán, Chile; guisella.tobar1901@alumnos.ubiobio.cl (G.T.-B.); \\ nidia.casas1701@alumnos.ubiobio.cl (N.C.-F.); gpetzold@ubiobio.cl (G.P.) \\ 3 Magíster en Ciencias e Ingeniería en Alimentos, Universidad del Bío-Bío, Av. Andrés Bello 720, Casilla 447, \\ 3780000 Chillán, Chile \\ 4 Doctorado en Ingeniería de Alimentos, Universidad del Bío-Bío, Av. Andrés Bello 720, Casilla 447, \\ 3780000 Chillán, Chile \\ 5 Programa Institucional de Fomento a la I+D+i, Universidad Tecnológica Metropolitana, \\ Ignacio Valdivieso 2409, San Joaquín, 8940577 Santiago, Chile \\ * Correspondence: p.orellanap@utem.cl; Tel.: +56-2-2787-7032
}

Received: 28 August 2020; Accepted: 16 September 2020; Published: 18 September 2020

\begin{abstract}
This study aimed to evaluate the potential of centrifugal block cryoconcentration (CBCC) at three cycles applied to fresh calafate juice. The fresh juice and cryoconcentrate at each cycle were stored for five weeks at $4{ }^{\circ} \mathrm{C}$ and quality attributes were analyzed every 7 days. CBCC had significant effects in the calafate juice, since in the last cycle, the cryoconcentrate reached a high value of total soluble solids (TSS, $\approx 42{ }^{\circ}$ Brix), with final attractive color, and an increase of approximately 2.5, 5.2, 5.1, 4.0 and 5.3 times in relation to the fresh juice values, for total bioactive compounds (TBC), 2,2-diphenyl-1-picrylhydrazyl (DPPH), 2,2'-azino-bis(3-ethylbenzothiazoline-6-sulfonic acid) (ABTS), ferric reducing antioxidant power (FRAP) and oxygen radical absorbance capacity (ORAC), respectively. However, at 35 days under storage, these values decreased by $5 \%, 13 \%, 15 \%, 19 \%, 24 \%$ and 27\%, for TSS, TBC, DPPH, ABTS, FRAP and ORAC, respectively. Additionally, until the day 14, the panelists indicated a good acceptability of the reconstituted cryoconcentrate. Therefore, CBCC can be considered a novel and viable technology for the preservation of quality attributes from fresh calafate juice with interesting food applications of the cryoconcentrates due to their high stability during storage time in comparison to the fresh juice.
\end{abstract}

Keywords: cryoconcentration; calafate juice; storage time; physicochemical properties; bioactive compounds; antioxidant activity; sensorial analysis

\section{Introduction}

Calafate (Berberis microphylla) has presented unique properties due to the high variety of health associated compounds, such as phenols, vitamins, minerals and amino acids [1]. Calafate belongs to the family Berberidaceae, and the fruits are harvested in numerous Chilean and Argentinian Patagonian sectors [2]. However, calafate production is still low compared to other berries (2019: 0.2 hectares calafate versus 970.6, 9.0 and 2.9 hectares of blueberries (Vaccinium corymbosum), maqui (Aristotelia chilensis) and michay (Berberis darwinii), respectively). Therefore, different technologies have 
been applied to keep this fruit available throughout the year. Thus, processed products from fresh calafate fruits such as juice, jellies, jams and wines can be found in local markets [3].

In recent decades, traditional thermal methods (evaporation, pasteurization and/or sterilization) have been used in fresh juice, and thus, the thermally treated concentrate products achieve a significant improvement in quality and prolonged shelf-life when compared to the fresh juice. Unfortunately, these technologies use high temperatures that cause undesirable changes on different properties (nutrients, flavor and color, among others), since these quality properties contain endless thermolabile and thermostable compounds that are degraded, and thus, the organoleptic properties are affected, resulting in possible rejection by consumers [4]. Hence, emerging non-thermal technologies have been investigated in the food processing sector to concentrate liquids, and thus, to retain their quality attributes [5].

Cryoconcentration (CC) is a non-thermal concentration technology which has demonstrated numerous advantages to preserve important properties in liquid foods [6]. Specifically, CC concentrates a liquid solution by total or partial freezing of water, and thus, as the temperature decreases the solutes are rejected from the ice phase and accumulate at the solid-liquid interphase, i.e., the cryoconcentrated (unfrozen liquid fraction) is between the ice crystals (solid water). Once the freezing process is finished, the cryoconcentrate is removed from the ice fraction, which allows lower energy consumption than thermal processing ( 0.33 versus $2.26 \mathrm{~kJ} / \mathrm{g}$, respectively) [7].

Different $C C$ techniques can be found in the literature, with block CC (BCC) characterized by the easier fraction separation, equipment used and operation procedures [8]. Specifically, in BCC, a liquid solution is completely frozen, which is equivalent to a frozen block solution. Later, the block sample is thawed and separated by a natural (gravitational) method [9] or by employing assisted techniques to improve the process parameters involved in BCC, among them, efficiency, solute yield and percentage of concentrate [10-12].

Hence, $\mathrm{BCC}$ has proven to be an environmentally friendly emerging technology with great potential to retain various quality characteristics in fresh fruit juice, including physicochemical parameters [13], phenolic content [14], antioxidant activity [15] and volatile compounds [16]. In addition, sensory panelists did not find differences between reconstituted cryoconcentrate samples and fresh juice [17]. Nevertheless, to our knowledge, no researches have been published on quality characteristics obtained from a fresh native juice such as calafate juice by BCC. Therefore, the novelty of this study is the concentration of calafate juice, an endemic species of the Patagonian Andes of Chile and Argentina considered as a "superfruit" with high polyphenol content and high antioxidant capacity through a green and non-thermal technology called cryoconcentration.

Therefore, the aim of the study was to investigate the stability of fresh calafate juice and cryoconcentrate samples, in quality attributes terms, during 35 days of storage after applied centrifugal BCC (CBCC) technology. The physicochemical parameters, bioactive compounds content, antioxidant activity and sensory analysis were studied in each week of the storage period.

\section{Materials and Methods}

\subsection{Calafate Juice Preparation}

Fresh calafate (Berberis microphylla) were harvested in southernmost Chile (XI Región de Aysén) (December 2019), and the fruits were transferred in a refrigerated truck to Chillán (Región del Nuble, Chile). The fruits were pressed, and then, the juice was filtered through nylon cloth ( $0.8 \mathrm{~mm}$ fine-mesh) to discard solid parts (peel and seeds) that might interfere with the CBCC process. The liquid sample was stored at $4{ }^{\circ} \mathrm{C}$ and processed within $24 \mathrm{~h}$.

\subsection{CBCC Protocol}

The CBCC process was carried out as described in our previous study [18]. Thus, the prepared calafate juice $(45 \mathrm{~mL})$ was placed in plastic centrifugal tubes with foamed polystyrene (around the 
tube) to produce an axial freezing. The samples were frozen at $-20{ }^{\circ} \mathrm{C}$ (overnight) in a vertical static freezer (280, M and S Consul, Sao Paulo, Brazil), and at the end of the freezing stage, the frozen samples were transported to centrifuge equipment (Eppendorf 5430R, Hamburg, Germany). Specifically, two centrifugation conditions (15 min with $4000 \mathrm{rpm}$ and $20 \mathrm{~min}$ with $4000 \mathrm{rpm}$ ) were performed to determine the best separation condition, considering total soluble solids (TSS), efficiency (Eff, \%) and final cryoconcentrate volume $(\mathrm{mL})$. Thereby, the centrifugation was used as an assisted technique to force the extraction of the cryoconcentrated fraction $\left(C_{s}\right)$ from the frozen matrix $\left(C_{f}\right)$. The $C B C C$ was performed at three cycles, i.e., the $C_{s}$ at the first cycle was used as feed solution for the second cycle and the second $\mathrm{C}_{\mathrm{s}}$ was used for the third cycle.

\subsection{Physicochemical Analysis}

The TSS was determined using a digital refractometer PAL-3 (range: 0-93 ${ }^{\circ}$ Brix, precision: $\pm 0.1^{\circ}$ Brix, Atago Inc., Tokyo, Japan). The density $\left(\mathrm{kg} / \mathrm{m}^{3}\right)$ of the samples was determined by the pycnometric method at $20^{\circ} \mathrm{C}$ using distilled water as a model liquid [19]. A digital pH meter HI 2221 (Hanna Instruments, Woonsocket, RI, USA) was used to determine the $\mathrm{pH}$ of the samples, and the mean $\mathrm{pH}$ values were calculated on the International Union of Pure and Applied Chemistry (IUPAC) recommendation [20]. The titratable acidity (TA) was measured by using $5 \mathrm{~mL}$ of sample mixed with $50 \mathrm{~mL}$ of degassed deionized water, $\mathrm{pH}$ of samples was adjusted to 8.2 with sodium hydroxide solution $(0.1 \mathrm{M} \mathrm{NaOH})$ and the TA was expressed as grams of malic acid (MA) per liter of sample (g MA/L). The color parameters were calculated on the International Commission on Illumination (CIE) with L* (Lightness), a* (Green-red axis) and b* (Blue-yellow axis) space (CIELAB) using a spectrophotometer CM-5 (Konica Minolta, Osaka, Japan). The standard illuminant and observer angle were D65 and $10^{\circ}$, respectively. In addition, the total color difference $\left(\Delta \mathrm{E}^{*}\right)$ between fresh calafate juice and cryoconcentrated samples was calculated according to Equation (1).

$$
\Delta \mathrm{E}^{*}=\sqrt{\left(\Delta \mathrm{L}^{*}\right)^{2}+\left(\Delta \mathrm{a}^{*}\right)^{2}+\left(\Delta \mathrm{b}^{*}\right)^{2}}
$$

where $\Delta \mathrm{L}^{*}, \Delta \mathrm{a}^{*}$ and $\Delta \mathrm{b}^{*}$ are differences between fresh calafate juice and cryoconcentrated samples at each week of the storage period.

TSS, $\mathrm{pH}$, acidity, density and color determinations of fresh juice and cryoconcentrated samples were performed in triplicate at ambient temperature $\left(\approx 22{ }^{\circ} \mathrm{C}\right)$. Three replicates for each treatment were analyzed.

\subsection{Quantification of Total Bioactive Compound (TBC)}

The total polyphenol content (TPC), total anthocyanin content (TAC) and total flavonoid content (TFC) of fresh calafate juice and cryoconcentrated samples were measured at each CBCC cycle and each storage period.

TPC was determined through the Folin-Ciocalteau method [21]. Wherein, $200 \mu \mathrm{L}$ of sample and $1500 \mu \mathrm{L}$ of diluted (1:10) Folin-Ciocalteau reagent were mixed. After $5 \mathrm{~min}, 1500 \mu \mathrm{L}$ of sodium carbonate solution $\left(20 \%(w / v), \mathrm{Na}_{2} \mathrm{CO}_{3}\right)$ was added to the solution. After $90 \mathrm{~min}$ in the dark at room temperature (incubation), the absorbance was measured at $760 \mathrm{~nm}$. Gallic acid (GA) was used for the standard curve construction, and the TPC results were expressed as mg of gallic acid equivalents (GAE) per grams (g) of dry matter (mg GAE/g d.m.).

TAC was quantified using the $\mathrm{pH}$ differential method [22]. Therefore, $200 \mu \mathrm{L}$ of sample was added to $1800 \mu \mathrm{L}$ of potassium chloride $(\mathrm{pH} 1.0,0.025 \mathrm{M}, \mathrm{KCl})$ and $1800 \mu \mathrm{L}$ of sodium acetate $(\mathrm{pH} 4.5,0.4 \mathrm{M}$, $\mathrm{CH}_{3} \mathrm{COONa}$ ). After $30 \mathrm{~min}$ in the dark at room temperature (incubation), the absorbance was measured at 520 and $700 \mathrm{~nm}$. Cyanidin-3-glucoside (C3G) was used for the standard curve construction, and the TAC results were expressed as $\mathrm{mg}$ of $\mathrm{C} 3 \mathrm{G}$ equivalent per grams ( $\mathrm{g}$ ) of dry matter (mg C3G/g d.m.).

TFC was measured by the aluminum chloride colorimetric method [23]. As such, $250 \mu \mathrm{L}$ of sample was mixed with $1000 \mu \mathrm{L}$ of distilled water and $75 \mu \mathrm{L}$ of sodium nitrite solution $(5 \%(w / v)$, 
$\mathrm{NaNO}_{2}$ ). After $10 \mathrm{~min}, 75 \mu \mathrm{L}$ of aluminum chloride $\left(10 \%(w / v), \mathrm{AlCl}_{3}\right), 500 \mu \mathrm{L}$ of sodium hydroxide $(1 \mathrm{M}, \mathrm{NaOH})$ and $600 \mu \mathrm{L}$ of distilled water were added. After $30 \mathrm{~min}$ in the dark at room temperature (incubation), the absorbance was measured at $510 \mathrm{~nm}$. Catequin (C) was used for the standard curve construction, and the results were expressed as $\mathrm{mg}$ of catechin equivalent (CE) per grams ( $\mathrm{g}$ ) of dry matter (mg CE/g d.m.).

All TBC determinations were evaluated using a spectrophotometer T70 UV-VIS (Oasis Scientific Inc., Greenville, SC, USA), and were done in triplicate at $\approx 22{ }^{\circ} \mathrm{C}$.

\subsection{Total Antioxidant Activity (TAA) Determinations}

Four methods were used to quantify antioxidant activity, the 2,2-diphenyl-1-picrylhydrazyl (DPPH), 2,2' -azino-bis(3-ethylbenzothiazoline-6-sulphonic acid) (ABTS), ferric reducing antioxidant power (FRAP) and oxygen radical absorbance capacity (ORAC) assays, with minor modifications.

DPPH assay was determined using the protocol described by Brand-Williams et al. [24]. Thereby, $100 \mu \mathrm{L}$ of sample was added to $2900 \mu \mathrm{L}$ of DPPH solution $(0.1 \mathrm{mM})$. The solution was incubated in the dark at room temperature $\left(\approx 22^{\circ} \mathrm{C}\right)$ for $30 \mathrm{~min}$, and then, the absorbance was measured at $515 \mathrm{~nm}$.

ABTS assay was performed according to Re et al. [25]. Therein, $10 \mu \mathrm{L}$ of sample was added to $990 \mu \mathrm{L}$ of ABTS solution. The sample was incubated in the dark at room temperature for $30 \mathrm{~min}$, and then, the absorbance was measured at $734 \mathrm{~nm}$.

FRAP assay was done according to the method described by Benzie and Strain [26]. As such, $100 \mu \mathrm{L}$ of sample, $3000 \mu \mathrm{L}$ of FRAP reagent and $300 \mu \mathrm{L}$ of water were mixed. The sample was incubated in the dark at $37^{\circ} \mathrm{C}$ for $10 \mathrm{~min}$, and then, the absorbance was measured at $593 \mathrm{~nm}$.

DPPH, ABTS and FRAP assays were quantified on a spectrophotometer T70 (UV-VIS spectrophotometer, Oasis Scientific Inc., Greenville, SC, USA).

ORAC assay was determined using the method reported by Ou et al. [27]. Specifically, $30 \mu \mathrm{L}$ of sample and $20 \mu \mathrm{L}$ of fluorescein solution $(10 \mathrm{nM})$ were placed into black 96-well microplates and incubated at $37^{\circ} \mathrm{C}$ for $30 \mathrm{~min}$. Then, $50 \mu \mathrm{L}$ of 2,2'-azobis(2-amidinopropane) dihydrochloride (AAPH, $600 \mathrm{mM}$ ) and $2900 \mu \mathrm{L}$ of phosphate buffer $(75 \mathrm{mM}, \mathrm{pH} 7.4)$ were added to the solution. The absorbance was measured every $1 \mathrm{~min}$ for $60 \mathrm{~min}$ at an excitation wavelength of $485 \mathrm{~nm}$ and an emission set of $520 \mathrm{~nm}$ using a multimode plate reader (Victor X3, Perkin Elmer, Hamburg, Germany).

For all assays, Trolox (T) (6-hydroxy-2,5,7,8-tetramethylchroman-2-carboxylic acid) was used for the standard curve construction, and the TAA results were expressed as $\mathrm{mM}$ Trolox equivalents (TE) per gram (g) of dry matter (mM TE/g d.m.) and the TAA determinations were performed in triplicate.

\subsection{Storage Study}

The fresh calafate juice and each cryoconcentrate sample were deposited in glass jars previously rinsed with distilled water and UV exposed for $1.5 \mathrm{~h}$. All the samples were stored at $4 \pm 1{ }^{\circ} \mathrm{C}$ in a refrigerated incubator (FOC 215E, Velp Scientific Inc., Milano, Italy) for 35 days. The physicochemical properties, TBC and TAA determinations were analyzed at day 0 (control) and after 7, 14, 21, 28 and 35 days, as previously described.

\subsection{Sensory Evaluation}

A sensorial analysis was done to measure the degree of acceptance or rejection between reconstituted cryoconcentrated samples (third cycle with similar TSS value than the fresh juice) and fresh calafate juice. The evaluations were performed at day $0,7,14$ and 21 of the storage period by a trained sensory panel consisting of ten males and ten females with an average age of 33 years old (from 27 to 39 years old). The samples were rated according to a 5-score hedonic scale system, in which $1=$ dislike extremely and $5=$ like extremely. Thus, odor, aroma, flavor and overall acceptability were evaluated. Specifically, $20 \mathrm{~mL}$ of samples at $22{ }^{\circ} \mathrm{C}$ were placed in transparent cups, labeled with three random numbers. Cold water and crackers were supplied to each panelist in each test for rinsing their mouths between the samples. Three replicates were performed on each sample. 


\subsection{Statistical Analysis}

The results were expressed as means \pm standard deviation. All statistical analysis was evaluated by analysis of variance (ANOVA) test and the treatment means were compared via least significant difference (LSD) or Student's t-test at level of significance $(p \leq 0.05)$. Statgraphics Centurion XVI software version 16.2.04 (StatPoint Technologies Inc. Warrenton, VA, USA) was used for analysis of data. Correlations between TBC, TAA and among them were evaluated by Pearson's correlation coefficient test.

\section{Results and Discussion}

\subsection{Preliminary Centrifugation Results}

In order to determine an adequate CBCC process, two centrifugation time conditions (15 $\mathrm{min}$ and $20 \mathrm{~min}$ ) were used to identify the best separation performance. The other conditions were similar to that previously reported in our laboratory, i.e., $4000 \mathrm{rpm}$ and $20^{\circ} \mathrm{C}$ as centrifugation speed and separation temperature, respectively [16-18].

The centrifugation time had an important effect in TSS, efficiency and final cryoconcentrate volume, with significant differences $(p \leq 0.05)$ at each cycle (Table 1$)$. Firstly, a gradual increase in TSS values was observed as cycles progressed, in both $15 \mathrm{~min}$ and $20 \mathrm{~min}$ conditions. However, at $15 \mathrm{~min}$ of centrifugation, the TSS values $\left(27,38\right.$ and $45^{\circ}$ Brix) were higher than those at $20 \mathrm{~min}(24,31$ and $37^{\circ}$ Brix), in the first, second and the third cycle, respectively. These results could be attributed to the centrifugation which remained relatively intact the ice fraction (without thawing and/or breaking) using $15 \mathrm{~min}$ as centrifugation time, and thus, only cryoconcentrate was extracted from the ice fraction.

Table 1. Preliminary results obtained at different centrifugation conditions.

\begin{tabular}{|c|c|c|c|c|}
\hline Centrifugation & Cvcle & TSS & Efficiency $^{1}$ & Cryoconcentrated Volume \\
\hline Condition & & $\left({ }^{\circ}\right.$ Brix $)$ & (Eff, \%) & $(\mathrm{CV}, \mathrm{mL})$ \\
\hline \multirow[t]{2}{*}{ Fresh juice } & 0 & $14.6 \pm 0.2^{a}$ & - & - \\
\hline & 1 & $27.2 \pm 0.8^{b}$ & $68.9 \pm 0.9^{a}$ & $28.6 \pm 0.2^{a}$ \\
\hline \multirow[t]{3}{*}{$15 \mathrm{~min}, 4000 \mathrm{rpm}, 20^{\circ} \mathrm{C}$} & 2 & $37.6 \pm 0.4^{c}$ & $57.9 \pm 0.4^{b}$ & $22.4 \pm 0.6^{b}$ \\
\hline & 3 & $44.5 \pm 0.5^{d}$ & $52.3 \pm 1.1^{c}$ & $15.2 \pm 0.8^{c}$ \\
\hline & 1 & $23.7 \pm 0.7^{b}$ & $75.7 \pm 1.0^{\mathrm{a}}$ & $34.4 \pm 0.6^{\mathrm{a}}$ \\
\hline \multirow[t]{2}{*}{$20 \mathrm{~min}, 4000 \mathrm{rpm}, 20^{\circ} \mathrm{C}$} & 2 & $31.1 \pm 0.6^{c}$ & $69.7 \pm 0.9^{b}$ & $29.1 \pm 1.0^{b}$ \\
\hline & 3 & $36.6 \pm 0.3^{d}$ & $63.0 \pm 0.5^{c}$ & $21.6 \pm 0.7^{c}$ \\
\hline
\end{tabular}

Total soluble solids (TSS), efficiency (Eff) and cryoconcentrate volume (CV). Different superscripts in a column are significantly different $(p \leq 0.05)$ according to least significant difference $(\mathrm{LSD})$ test. ${ }^{1} \operatorname{Eff}(\%)=\left(\left(\mathrm{C}_{\mathrm{cs}}-\mathrm{C}_{\mathrm{cf}}\right) / \mathrm{C}_{\mathrm{cs}}\right) * 100$, where $\mathrm{C}_{\mathrm{cs}}$ and $\mathrm{C}_{\mathrm{cf}}$ are the solutes in cryoconcentrated and ice fraction, respectively.

An inverse behavior was observed in efficiency, since $20 \mathrm{~min}$ presented better results than $15 \mathrm{~min}$, with $63 \%$ and $52 \%$, in the last cycle, respectively. This phenomenon can be described by the TSS concentration values in the $\mathrm{C}_{\mathrm{s}}$ and $\mathrm{C}_{\mathrm{f}}$ fractions in each cycle, since a high TSS value produces an increase in viscosity and thus, an increase the difficulty of solute extraction from the ice matrix, which produces a reduction in the separation efficiency [28].

An important point to determine the best centrifugation condition is the cryoconcentrate volume $(\mathrm{CV})$, which decreased as the cycles advanced. In our case, centrifugation for $20 \mathrm{~min}$ presented higher $\mathrm{CV}$ post-centrifugation by tube than $15 \mathrm{~min}$, from $\approx 34$ to $\approx 22 \mathrm{~mL}$ and $\approx 29$ to $\approx 15 \mathrm{~mL}$, respectively. These results can be correlated with the previously results obtained in TSS, since, as mentioned above, a high TSS value increases the viscosity, and this behavior influences the CV obtained due to the high viscosity preventing the solutes movement outside from the frozen phase.

Therefore, we defined $20 \mathrm{~min}$ as centrifugation time for the separation between $C_{S}$ and $C_{f}$ at each cycle, since it allows a higher CV extraction than $15 \mathrm{~min}$. In addition, calafate (Berberis microphylla) is still a fruit with low production in Chile compared to other berries [29], and to date, these fruits present 
a high price per kilogram due to recent knowledge acquired on different quality properties [1-3], which encourages the cryoconcentrated juice study and stability over time for the elaboration of different products such as fruit juice.

\subsection{TSS Results}

The fresh juice has an initial TSS value close to $13.9^{\circ}$ Brix (Figure 1), which is a value within the range established by Mariangel et al. [3], who studied the variability in numerous attributes of calafate fruit harvested from four sectors in Southern Chile, with TSS values between 9.3 to $22.9^{\circ} \mathrm{Brix}$, which reflects the influence of different agricultural and climatic conditions on the fruit growth pattern.

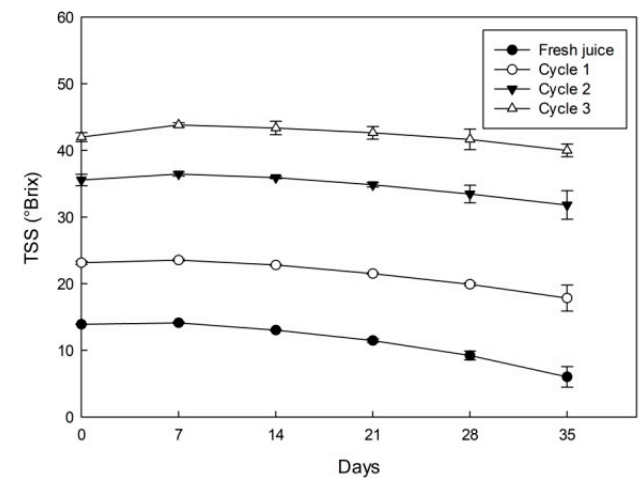

Figure 1. Effect of storage on TSS in fresh and cryoconcentrated calafate juice.

Firstly, in relation to day 0 , the TSS in the fresh juice increased significantly cycle to cycle with values of $23.1,35.6$ and $42.0^{\circ}$ Brix in the first, second and third cycle, which is equivalent to a concentration index $\left(\mathrm{CI}\right.$, ratio $\left.\mathrm{C}_{\mathrm{s}} / \mathrm{C}_{0}\right)$ of $1.7,2.6$ and 3.0 times, compared to the initial TSS value $\left(13.9^{\circ}\right.$ Brix), respectively. Thus, the TSS results at each cycle have higher values than those achieved in previous investigations with other fresh fruit juice samples such as blueberry juice [18,30], orange juice [10] and pineapple juice [16] under similar conditions in our laboratory, with final concentration values (third cycle) close to $41,33,40$ and $36^{\circ}$ Brix, respectively. Furthermore, the TSS values were superior to those described by Moreno et al. [31] and Ding et al. [32], who used BCC and suspension CC (SCC) to cryoconcentrate coffee extract and apple juice, respectively. Hence, the TSS values variation could be explained by the freezing conditions and sized tubes capacity used in the present study. Specifically, we used an axial freezing front propagation with moderate freezing rate temperature $\left(-20^{\circ} \mathrm{C}\right)$, which allows an improved counter-diffusion of solutes from the growing crystal surface. Additionally, the centrifugal equipment has a sized tubes capacity of $50 \mathrm{~mL}$-tube, which favors the cryoconcentrate extraction from the ice frozen in the centrifugation step [18].

During the first week (day 7) under storage, the TSS in the fresh juice presented a slight increase (with statistical differences) compared with control juice (day 0). However, a continuous decline in TSS was observed in the next weeks, with a final value of approximately $6.0^{\circ}$ Brix at day 35 (week 5), which is equivalent to a decrease of more than $57 \%$ of the initial TSS value (day 0 ). A similar effect was observed for all CBCC cycles, with a slight increase until day 7, and then, TSS decreased significantly until day 35 , where it reached values close to $17.8,31.8$ and $40.0^{\circ}$ Brix, for the first, second and third cycle, which indicates a decrease of $23 \%, 11 \%$ and $5 \%$, with respect to the correspondent value at day 0 , respectively.

The TSS decrease at each cycle under storage could be associated with sugar consumption by microorganisms, since as time progresses, there exists a possibility of microbial growth, and thus, as days passed, the microorganisms consume higher sugar amount than in the first days (first week), reflecting in a gradual TSS decrease [33]. Comparable results were described by Wahia et al. [34], who studied melon juice and their quality properties preservation at various days during storage. Additionally, Chia et al. [35] mentions that, in terms of consumption safety, the unpasteurized products 
has a shelf life up to two weeks, since, in general, the fresh fruits have a microbial load close to 3 to 5 $\log \mathrm{CFU}$ per $\mathrm{mL}$ and the limit is $6 \log \mathrm{CFU}$ per $\mathrm{mL}$.

\subsection{Physicochemical Analysis}

Statistical differences $(p \leq 0.05)$ were found in density, $\mathrm{pH}$ and acidity values between the fresh juice and their respective CBCC cycle, and in turn, significant differences $(p \leq 0.05)$ were observed between the samples (at day 0 ) and their correspondent at each week under storage (Table 2).

Firstly, the initial $\mathrm{pH}$ and TA values in the calafate juice (day 0 ) were equivalent to those previously reported by Arena et al. [36], who studied the organic acids content of calafate in different growing seasons, specifying that the physicochemical properties of calafate depends on various aspects such as climate, place of growth, type of harvest and processing procedures.

Specifically, in the fresh juice (day 0 ) and as the cycles advanced, a gradual decrease in the $\mathrm{pH}$ values were observed, with a decrease close to $2.3 \%, 5.5 \%$ and $8.7 \%$ in relation to the initial $\mathrm{pH}$ value ( $\mathrm{pH} \approx 3.09$ ), for the cycle one, cycle two and cycle three, respectively. While, an opposite effect was denoted in TA values, since it presented a considerable increase, with values of approximately 2.1, 2.8, 4.1 and 4.6, from fresh juice to the final CBCC cycle, respectively. This contrary performance has been linked to the TSS and their values cycle by cycle, i.e., as TSS increased, an increase in the organic acid content was generated, affecting the $\mathrm{pH}$ and TA values [37]. Besides, the results are in accordance with those obtained in CC applied to pineapple juice [16], apple juice [17] and blueberry juice [38], in which all the cryoconcentrated juices had antagonistic values in $\mathrm{pH}$ and TA with the increase in solutes as the cycles passed.

On the days under storage, an opposite behavior was observed in each sample among $\mathrm{pH}$ and TA values, since a progressive increase was detected in $\mathrm{pH}$ and a significant decline was identified in TA, with values from 3.1 to 3.4 and 2.1 to 1.7 for fresh juice, 3.0 to 3.3 and 2.8 to 2.3 for cycle one, 2.9 to 3.2 and 4.1 to 3.6 for cycle two and 2.8 to 3.2 and 4.6 to 4.0 for cycle three, from the day 0 to day 35 , respectively. In this case, this phenomenon has been attributed to the acid hydrolysis of various polysaccharides, in which the non-reducing sugars are transformed into reducing sugars, as well as the use of malic acid as an energy source by microorganisms [39].

In general terms, the fruit juices are a good media for microbial multiplication and spoilage, with a usual microbial increase during storage time. In these conditions, the microorganisms use nutrients and cause enzymatic changes, contributing to creating off-flavor by breakdown or synthesis of new compounds [40]. In the case of unpasteurized fruit juices, the microbial spoilage is most commonly the result of aciduric microbes such as lactic acid bacteria and yeasts that produce copious quantities of carbon dioxide and off-flavors [41].

Similar trends were perceived in fruit juices such as sugarcane juice [42], grape juice [43] and apple juice [44] during storage.

In terms of density, the values showed an overall increasing trend from the fresh juice to the last cycle at day 0 , and thus, the density values presented an increase close to $5 \%, 8 \%$ and $12 \%$ in comparison to the respective initial value. This behavior can be justified by the TSS concentration reached post-centrifugation step at each cycle [45] and the performance was comparable with the results informed for different cryoconcentrated juices $[16,17,38,45]$. In addition, a similar behavior was observed throughout storage, since at day 35 , the density showed an increment of approximately $12-14 \%$ to the respective sample at day 0 . These trends might be explained by the water evaporation in the sample under storage period, which lead to a decrease in the volume of the sample, as it was explained in studies on physicochemical properties under storage conditions for watermelon juice [33] and grape juice [46]. 
Table 2. Physicochemical parameters of fresh calafate juice and cryoconcentrate samples during storage.

\begin{tabular}{|c|c|c|c|c|c|c|c|c|c|c|c|c|}
\hline \multirow{2}{*}{ Day } & \multicolumn{4}{|c|}{$\mathrm{pH}$} & \multicolumn{4}{|c|}{ TA (g MA/L) } & \multicolumn{4}{|c|}{ Density $\left(\mathrm{kg} / \mathrm{m}^{3}\right)$} \\
\hline & Fresh Juice & $\mathrm{C} 1$ & $\mathrm{C} 2$ & $\mathrm{C} 3$ & Fresh Juice & C1 & $\mathrm{C} 2$ & $\mathrm{C} 3$ & Fresh Juice & C1 & $\mathrm{C} 2$ & $\mathrm{C} 3$ \\
\hline 0 & $3.09 \pm 0.01^{\mathrm{a}, \mathrm{A}}$ & $3.02 \pm 0.01 \mathrm{~b}, \mathrm{~A}$ & $2.92 \pm 0.02^{c, A}$ & $2.82 \pm 0.02 \mathrm{~d}, \mathrm{~A}$ & $2.07 \pm 0.01^{\mathrm{a}, \mathrm{A}}$ & $2.77 \pm 0.05^{\mathrm{b}, \mathrm{A}}$ & $4.10 \pm 0.09^{c, A}$ & $4.59 \pm 0.06^{\mathrm{d}, \mathrm{A}}$ & $1030 \pm 3.55^{\mathrm{a}, \mathrm{A}}$ & $1080 \pm 5.92^{b, A}$ & $1110 \pm 9.01^{\mathrm{c}, \mathrm{A}}$ & $1150 \pm 3.77^{\mathrm{d}, \mathrm{A}}$ \\
\hline 7 & $3.15 \pm 0.02 \mathrm{a}, \mathrm{B}$ & $3.07 \pm 0.02 \mathrm{~b}, \mathrm{~B}$ & $3.00 \pm 0.03 c, B$ & $2.89 \pm 0.00 \mathrm{~d}, \mathrm{~B}$ & $2.03 \pm 0.02 \mathrm{a}, \mathrm{B}$ & $2.65 \pm 0.02^{b, B}$ & $3.97 \pm 0.02 \mathrm{c}, \mathrm{B}$ & $4.40 \pm 0.08 \mathrm{~d}, \mathrm{~B}$ & $1040 \pm 2.74 \mathrm{a}, \mathrm{B}$ & $1100 \pm 10.14 \mathrm{~b}, \mathrm{~B}$ & $1140 \pm 5.74$ c, B & $1160 \pm 4.58^{\mathrm{d}, \mathrm{B}}$ \\
\hline 14 & $3.24 \pm 0.01^{\mathrm{a}, \mathrm{C}}$ & $3.18 \pm 0.00^{\mathrm{b}, \mathrm{C}}$ & $3.05 \pm 0.01 \mathrm{c}, \mathrm{C}$ & $3.01 \pm 0.01 \mathrm{~d}, \mathrm{C}$ & $1.98 \pm 0.00^{\mathrm{a}, \mathrm{C}}$ & $2.59 \pm 0.01^{b, C}$ & $3.90 \pm 0.01^{c, C}$ & $4.25 \pm 0.05^{\mathrm{d}, \mathrm{C}}$ & $1060 \pm 3.01^{\mathrm{a}, \mathrm{C}}$ & $1130 \pm 6.63^{\mathrm{b}, \mathrm{C}}$ & $1160 \pm 2.10^{c, C}$ & $1200 \pm 10.15^{d, C}$ \\
\hline 21 & $3.30 \pm 0.03^{a}, \mathrm{D}$ & $3.21 \pm 0.01^{b, D}$ & $3.09 \pm 0.02 \mathrm{c}, \mathrm{D}$ & $3.06 \pm 0.00 \mathrm{~d}, \mathrm{D}$ & $1.84 \pm 0.02^{\mathrm{a}, \mathrm{D}}$ & $2.44 \pm 0.00^{b, D}$ & $3.82 \pm 0.03 \mathrm{c}, \mathrm{D}$ & $4.15 \pm 0.03 \mathrm{~d}, \mathrm{D}$ & $1090 \pm 10.75 \mathrm{a}, \mathrm{D}$ & $1150 \pm 11.25^{\mathrm{b}, \mathrm{D}}$ & $1180 \pm 11.52 \mathrm{c}, \mathrm{D}$ & $1240 \pm 12.00 \mathrm{~d}, \mathrm{D}$ \\
\hline 28 & $3.36 \pm 0.01 \mathrm{a}, \mathrm{E}$ & $3.25 \pm 0.02 \mathrm{~b}, \mathrm{E}$ & $3.17 \pm 0.03 \mathrm{c}, \mathrm{E}$ & $3.11 \pm 0.01 \mathrm{~d}, \mathrm{E}$ & $1.79 \pm 0.01 \mathrm{a}, \mathrm{E}$ & $2.37 \pm 0.01 \mathrm{~b}, \mathrm{E}$ & $3.75 \pm 0.02^{c, E}$ & $4.10 \pm 0.01 \mathrm{~d}, \mathrm{D}$ & $1120 \pm 9.95 \mathrm{a}, \mathrm{E}$ & $1170 \pm 4.12^{\mathrm{b}, \mathrm{E}}$ & $1210 \pm 3.58^{\mathrm{c}, \mathrm{E}}$ & $1270 \pm 6.83^{\mathrm{d}, \mathrm{E}}$ \\
\hline 35 & $3.40 \pm 0.02^{a, F}$ & $3.29 \pm 0.01^{b, F}$ & $3.22 \pm 0.01 \mathrm{c}, \mathrm{F}$ & $3.17 \pm 0.02^{\mathrm{d}, \mathrm{F}}$ & $1.72 \pm 0.03 \mathrm{a}, \mathrm{F}$ & $2.32 \pm 0.01 \mathrm{~b}, \mathrm{~F}$ & $3.62 \pm 0.04 \mathrm{c}, \mathrm{F}$ & $4.03 \pm 0.04 \mathrm{~d}, \mathrm{E}$ & $1150 \pm 12.10^{\mathrm{a}, \mathrm{F}}$ & $1200 \pm 6.58^{\mathrm{b}, \mathrm{F}}$ & $1250 \pm 4.50^{\mathrm{c}, \mathrm{F}}$ & $1310 \pm 4.45^{\mathrm{d}, \mathrm{F}}$ \\
\hline
\end{tabular}

a-d: Different small letters in the superscript in the same row denote differences at $5 \%$ between the fresh calafate juice and their cycles, according to the LSD test. A-F: Different capital letters in the superscript in the same column denote differences at 5\% in the sample during storage time, according to the LSD test. C1, C2 and C3 represents cycle 1 , cycle 2 and cycle 3 , respectively. 
Color parameters of fresh calafate juice and for each $\mathrm{CBCC}$ cycle during storage are shown in Table 3. The samples exhibited significant changes at each cycle, mentioning that the differences among the samples were quantitative and qualitative.

Table 3. CIELAB values of fresh calafate juice and cryoconcentrate samples during storage.

\begin{tabular}{|c|c|c|c|c|c|}
\hline Day & Sample & $\mathbf{L}^{*}$ & $a^{*}$ & $\mathbf{b}^{*}$ & $\Delta \mathrm{E}^{*}$ \\
\hline \multirow{4}{*}{0} & Fresh juice & $33.95 \pm 0.61^{a}$ & $31.21 \pm 2.72^{a}$ & $3.11 \pm 0.08^{a}$ & - \\
\hline & C1 & $21.71 \pm 1.01^{b}$ & $39.58 \pm 0.47^{b}$ & $2.68 \pm 0.24^{b}$ & $14.84 \pm 1.07^{a}$ \\
\hline & $\mathrm{C} 2$ & $10.41 \pm 0.51^{\mathrm{c}}$ & $43.40 \pm 0.34^{c}$ & $2.32 \pm 0.21^{b, c}$ & $26.52 \pm 0.34^{b}$ \\
\hline & $\mathrm{C} 3$ & $7.22 \pm 0.19^{d}$ & $46.71 \pm 0.29 \mathrm{~d}$ & $1.71 \pm 0.08^{\mathrm{d}}$ & $30.92 \pm 0.30^{c}$ \\
\hline \multirow{4}{*}{7} & Fresh juice & $32.05 \pm 0.09^{a}$ & $33.71 \pm 1.00^{a}$ & $3.04 \pm 0.05^{\mathrm{a}}$ & - \\
\hline & C1 & $16.85 \pm 0.23^{b}$ & $41.44 \pm 0.29^{b}$ & $2.02 \pm 0.02^{b}$ & $17.08 \pm 0.31^{a}$ \\
\hline & $\mathrm{C} 2$ & $8.37 \pm 0.14^{c}$ & $44.85 \pm 0.25^{c}$ & $1.41 \pm 0.13^{c}$ & $26.22 \pm 0.24^{b}$ \\
\hline & $\mathrm{C} 3$ & $5.49 \pm 0.26^{\mathrm{d}}$ & $48.45 \pm 0.28^{d}$ & $0.99 \pm 0.03^{\mathrm{d}}$ & $30.44 \pm 0.26^{c}$ \\
\hline \multirow{4}{*}{14} & Fresh juice & $31.12 \pm 0.15^{a}$ & $34.07 \pm 0.13^{a}$ & $3.00 \pm 0.01^{a}$ & - \\
\hline & C1 & $16.05 \pm 0.05^{b}$ & $41.94 \pm 0.08^{b}$ & $1.65 \pm 0.06^{b}$ & $17.05 \pm 0.06^{a}$ \\
\hline & $\mathrm{C} 2$ & $7.97 \pm 0.03^{c}$ & $45.07 \pm 0.07^{c}$ & $1.32 \pm 0.01^{c}$ & $25.68 \pm 0.04^{b}$ \\
\hline & $\mathrm{C} 3$ & $4.96 \pm 0.02^{\mathrm{d}}$ & $49.18 \pm 0.06^{\mathrm{d}}$ & $0.91 \pm 0.02 \mathrm{~d}$ & $30.28 \pm 0.03$ \\
\hline \multirow{4}{*}{21} & Fresh juice & $25.84 \pm 0.82^{a}$ & $37.36 \pm 0.32^{a}$ & $2.79 \pm 0.05^{\mathrm{a}}$ & - \\
\hline & C1 & $13.10 \pm 0.60^{b}$ & $43.41 \pm 0.35^{b}$ & $1.17 \pm 0.04^{b}$ & $14.20 \pm 0.45^{a}$ \\
\hline & $\mathrm{C} 2$ & $6.37 \pm 0.16^{c}$ & $46.48 \pm 0.35^{\mathrm{c}}$ & $1.06 \pm 0.06^{c}$ & $21.58 \pm 0.27^{b}$ \\
\hline & $\mathrm{C} 3$ & $3.10 \pm 0.05^{\mathrm{d}}$ & $50.46 \pm 0.31^{d}$ & $0.75 \pm 0.05^{\mathrm{d}}$ & $26.32 \pm 0.17^{c}$ \\
\hline \multirow{4}{*}{28} & Fresh juice & $20.25 \pm 0.30^{a}$ & $39.60 \pm 0.33^{a}$ & $2.33 \pm 0.27^{a}$ & - \\
\hline & $\mathrm{C} 1$ & $9.49 \pm 0.14^{b}$ & $45.30 \pm 0.27^{b}$ & $0.92 \pm 0.04^{b}$ & $12.26 \pm 0.16^{a}$ \\
\hline & $\mathrm{C} 2$ & $5.04 \pm 0.07^{c}$ & $48.31 \pm 0.33^{c}$ & $0.85 \pm 0.04^{\mathrm{c}}$ & $17.58 \pm 0.20^{b}$ \\
\hline & $\mathrm{C} 3$ & $1.97 \pm 0.02^{\mathrm{d}}$ & $52.34 \pm 0.28^{d}$ & $0.50 \pm 0.05^{\mathrm{d}}$ & $22.36 \pm 0.18^{c}$ \\
\hline \multirow{4}{*}{35} & Fresh juice & $13.57 \pm 0.45^{\mathrm{a}}$ & $41.73 \pm 0.24^{\mathrm{a}}$ & $1.99 \pm 0.04^{\mathrm{a}}$ & - \\
\hline & C1 & $6.13 \pm 0.02^{b}$ & $47.67 \pm 0.46^{b}$ & $0.53 \pm 0.03^{b}$ & $9.63 \pm 0.28^{a}$ \\
\hline & $\mathrm{C} 2$ & $3.69 \pm 0.15^{c}$ & $51.00 \pm 0.41^{\mathrm{c}}$ & $0.33 \pm 0.03^{c}$ & $13.65 \pm 0.38^{b}$ \\
\hline & $\mathrm{C} 3$ & $0.51 \pm 0.37^{\mathrm{d}}$ & $55.00 \pm 0.26^{\mathrm{d}}$ & $0.06 \pm 0.01^{\mathrm{d}}$ & $18.72 \pm 0.37^{c}$ \\
\hline
\end{tabular}

Different letters in the same column show significant differences at $5 \%$ between homogeneous groups in each variable to a LSD. C1, C2 and C3 represents cycle 1, cycle 2 and cycle 3, respectively. "-" corresponds to a control sample on the day of analysis.

At day 0 , the fresh calafate juice presented a light reddish violet color $\left(L^{*} \approx 34.0, a^{*} \approx 31.2\right.$ and $b^{*} \approx 3.1$. However, to date, there are no studies that report the CIELAB color coordinates for calafate juice, but the color can be related to other fruit juices with comparable tonality such as strawberry juice [15], blueberry juice [18] and pomegranate juice [47]. Thus, at each CBCC cycle, a remarkable modification with respect to the fresh juice was observed, since $L^{*}$ and $b^{*}$ values decreased, i.e., the concentrate samples were darker with a slight brown tone, while $\mathrm{a}^{*}$ values had a significant increase, demonstrating a trend from the light red to dark red color (Figure 2). This behavior could be accredited to the increase in TSS values, since as the cycles advanced; more concentrated solute was separated from the ice fraction, leading to an intensification of the natural fruit juice color. These CIELAB values presented concordance with previous results for cryoconcentrated orange juice [10], strawberry juice [15], blueberry juice [18] and apple juice [48,49], in which the juices were darker with marked increase in $\mathrm{a}^{*}$ and/or $\mathrm{b}^{*}$ coordinates, depending on the initial juice color, as the cycles increased. 


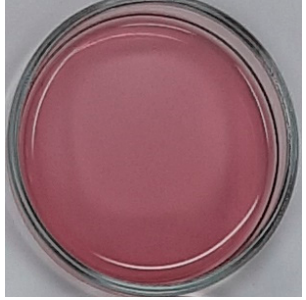

(a)

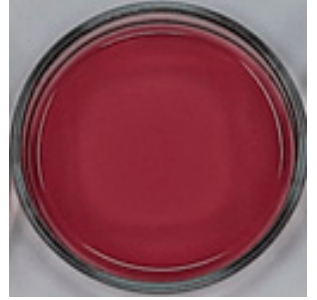

(b)

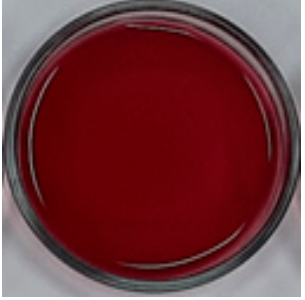

(c)

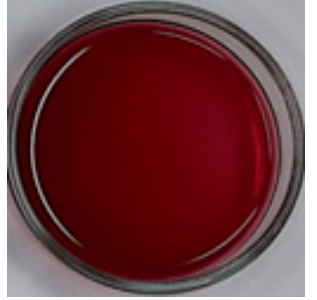

(d)

Figure 2. Visual appearance of samples: (a) fresh calafate juice; (b) cycle 1 ; (c) cycle 2; and (d) cycle 3.

In storage terms, at day 35 , the fresh juice offered a considerable decrease in the $\mathrm{L}^{*}$ and $\mathrm{b}^{*}$ values by $60 \%$ and $36 \%$, and $a^{*}$ values had an increase by $34 \%$ with respect to the initial CIELAB values (day 0 ), respectively. Similarly, in the last cycle, a pronounced decrease by $93 \%$ and $97 \%$ was observed in $\mathrm{L}^{*}$ and $\mathrm{b}^{*}$ values in comparison to the values in the same cycle at day $0\left(\mathrm{~L}^{*}=7.22\right.$ and $\left.\mathrm{b}^{*}=1.21\right)$, respectively. On the contrary, $a^{*}$ indicates an increase by $18 \%$ with respect to the third cycle at day $0\left(a^{*}=46.71\right)$. Comparable performances, under different days of storage, were reported by Igual et al. [46] for grape juice, Yildiz and Aadil [50] for strawberry juice and Wurlitzer [51] for tropical fruit juices, specifying that the darkening and tendency to brown color is due to the compounds degradation by factors such as nonenzymatic Maillard reaction, exposure to air and light, $\mathrm{pH}$ changes and enzymatic activities, which leads to the oxidation in the sample that alters the visual appearance of the juice. Furthermore, the visual color of fresh calafate juice and each cycle during storage are presented in the Supplementary Materials (Figure S1), in which it is possible to observe the change from light reddish violet (fresh juice, day 0) to an attractive dark reddishness color due to the components concentration in the fresh calafate juice, as the cycles advanced. However, as the days passed, the color had a darker tone, which turned a brown color (cycle two) and a dark brown color (cycle three), which displays the degradation throughout the storage period, as mentioned above.

According to $\Delta \mathrm{E}^{*}$ evaluation (Table 3 ), at day 0 , the values were over 14 CIELAB units, indicating that the human eye can find differences between fresh juice with each CBCC cycle, based on the scale proposed by Pankaj et al. [52] ( $\Delta \mathrm{E}^{*} \geq 3$, the color is humanly perceptible). The difference was more pronounced between fresh juice and the third cycle, since the $\Delta \mathrm{E}^{*}$ value was close to 31 units, indicating that the tendency to a dark reddish color generates a significant visual change to the fresh juice. As storage time passed, the $\Delta \mathrm{E}^{*}$ values were less noticeable than the samples at day 0 . These $\Delta \mathrm{E}^{*}$ values were clearly depending on the TSS in the sample, since a high $\Delta \mathrm{E}^{*}$ between the fresh juice and cryoconcentrates was obtained by increasing the TSS cycle to cycle, and in turn, it can be related with the change in $L^{*}$ values. As an important point, the decrease in the $\Delta \mathrm{E}^{*}$ values under storage time in comparison at day 0 is due to the progressive component degradation as days passed, with the color going from a light reddish violet to a red color, and from dark red to a dark brown, for the fresh juice and third cycle, from the day 0 to day 35 , respectively, reducing the visual perception when the samples were compared.

\subsection{TBC of Fresh and Cryoconcentrated Samples}

TBC values at day 0 and during storage time of fresh juice and cryoconcentrated samples are presented in Table 4.

The TBC values (TPC, TAC and TFC) in fresh calafate juice (day 0) were close to $54.7 \mathrm{mg} \mathrm{GAE} / \mathrm{g}$ d.m., $41.2 \mathrm{mg} \mathrm{C} 3 \mathrm{G} / \mathrm{g} \mathrm{d} . \mathrm{m}$. and $31.9 \mathrm{mg} \mathrm{CE} / \mathrm{g}$ d.m., respectively. These results were superior to those found by Brito et al. [53], who studied various bioactive components of native berries from VIII Region of Chile. The variations in TBC values could be due to the geographical characteristics in each Region, since there is a distance of approximately $1200 \mathrm{~km}$ between VIII Region and XI Region, which leads to diverse environmental conditions, genetic and species variabilities, affecting the time and form of fruit maturity and harvest-type method used by farmers, and thus, all these factors could explain the disparity between TBC values. 
Table 4. Total bioactive compounds (TBC) values of fresh calafate juice and cryoconcentrates during 35 days of storage.

\begin{tabular}{|c|c|c|c|c|c|c|c|c|c|c|c|c|}
\hline \multirow{2}{*}{ Day } & \multicolumn{4}{|c|}{ TPC (mg GAE/g d.m.) } & \multicolumn{4}{|c|}{ TAC (mg C3G/g d.m.) } & \multicolumn{4}{|c|}{ TFC (mg CE/g d.m.) } \\
\hline & Fresh Juice & $\mathrm{C} 1$ & $\mathrm{C} 2$ & C3 & Fresh Juice & $\mathrm{C} 1$ & $\mathrm{C} 2$ & C3 & Fresh Juice & $\mathrm{C} 1$ & $\mathrm{C} 2$ & $\mathrm{C} 3$ \\
\hline 0 & $\begin{array}{c}54.72 \pm 0.02 \\
\mathrm{a}, \mathrm{A}\end{array}$ & $\begin{array}{c}63.34 \pm 0.66 \\
b, A\end{array}$ & $\begin{array}{c}106.88 \pm \\
0.77^{c, A}\end{array}$ & $\begin{array}{l}147.20 \pm \\
0.04^{d, A}\end{array}$ & $\underset{\mathrm{a}, \mathrm{A}}{41.19 \pm 0.07}$ & $\begin{array}{c}46.65 \pm 0.65 \\
\mathrm{~b}, \mathrm{~A}\end{array}$ & $\underset{\mathrm{c}, \mathrm{A}}{77.32 \pm 0.48}$ & $\begin{array}{c}101.92 \pm \\
0.53 \mathrm{~d}, \mathrm{~A}\end{array}$ & $\begin{array}{c}31.89 \pm 0.45 \\
\mathrm{a}, \mathrm{A}\end{array}$ & $\underset{b, A}{35.11 \pm 0.58}$ & $\underset{\mathrm{c}, \mathrm{A}}{58.52 \pm 0.34}$ & $\begin{array}{c}76.89 \pm 0.41 \\
\mathrm{~d}, \mathrm{~A}\end{array}$ \\
\hline 7 & $\underset{\mathrm{a}, \mathrm{B}}{57.89 \pm 0.20}$ & $\underset{b, B}{69.18 \pm 0.38}$ & $\begin{array}{c}115.34 \pm \\
1.25^{\mathrm{c}, \mathrm{B}}\end{array}$ & $\begin{array}{l}163.05 \pm \\
2.30^{\mathrm{d}, \mathrm{B}}\end{array}$ & $\underset{\mathrm{a}, \mathrm{B}}{42.93 \pm 0.50}$ & $\underset{b, B}{50.02 \pm 0.40}$ & $\underset{c, B}{82.16 \pm 0.59}$ & $\begin{array}{c}110.55 \pm \\
5.35^{\mathrm{d}, \mathrm{B}}\end{array}$ & $\begin{array}{c}33.46 \pm 1.29 \\
\mathrm{a}, \mathrm{B}\end{array}$ & $\begin{array}{c}37.97 \pm 1.05 \\
\mathrm{~b}, \mathrm{~B}\end{array}$ & $\underset{c, B}{63.06 \pm 0.55}$ & $\underset{\mathrm{d}, \mathrm{B}}{85.11 \pm 0.08}$ \\
\hline 14 & $\begin{array}{c}52.61 \pm 0.38 \\
\mathrm{a}, \mathrm{C}\end{array}$ & $\begin{array}{c}61.80 \pm 0.31 \\
b, C\end{array}$ & $\begin{array}{c}105.70 \pm \\
4.34^{\mathrm{c}, \mathrm{C}}\end{array}$ & $\begin{array}{l}146.18 \pm \\
3.73^{\mathrm{d}, \mathrm{C}}\end{array}$ & $\begin{array}{c}38.35 \pm 0.59 \\
\mathrm{a}, \mathrm{C}\end{array}$ & $\begin{array}{c}44.35 \pm 0.21 \\
\mathrm{~b}, \mathrm{C}\end{array}$ & $\underset{c, C}{75.59 \pm 0.53}$ & $\begin{array}{c}100.85 \pm \\
4.28^{\mathrm{d}, \mathrm{C}}\end{array}$ & $\begin{array}{c}28.79 \pm 0.52 \\
a, C\end{array}$ & $\begin{array}{c}32.35 \pm 1.27 \\
\mathrm{~b}, \mathrm{C}\end{array}$ & $\underset{\mathrm{c}, \mathrm{C}}{56.17 \pm 0.56}$ & $\begin{array}{c}74.99 \pm 1.25 \\
\mathrm{~d}, \mathrm{C}\end{array}$ \\
\hline 21 & $\begin{array}{c}49.86 \pm 0.39 \\
\mathrm{a}, \mathrm{D}\end{array}$ & $\underset{\mathrm{b}, \mathrm{D}}{59.62 \pm 0.39}$ & $\begin{array}{c}103.74 \pm \\
0.97 \mathrm{c}, \mathrm{D}\end{array}$ & $\begin{array}{l}144.93 \pm \\
0.77^{d}, \mathrm{D}\end{array}$ & $\underset{\mathrm{a}, \mathrm{D}}{35.19 \pm 0.66}$ & $\underset{b, D}{41.51 \pm 0} 0.73$ & $\underset{\mathrm{c}, \mathrm{D}}{72.85 \pm 0.06}$ & $\begin{array}{c}99.34 \pm 3.59 \\
\mathrm{~d}, \mathrm{D}\end{array}$ & $\underset{\mathrm{a}, \mathrm{D}}{25.40 \pm 0.51}$ & $\underset{b, \mathrm{D}}{29.01 \pm 0.55}$ & $\underset{\mathrm{c}, \mathrm{D}}{52.04 \pm 0.34}$ & $\begin{array}{c}70.01 \pm 0.64 \\
\mathrm{~d}, \mathrm{D}\end{array}$ \\
\hline 28 & $\underset{\mathrm{a}, \mathrm{E}}{46.68 \pm 0.17}$ & $\begin{array}{c}56.67 \pm 1.09 \\
b, \mathrm{E}\end{array}$ & $\begin{array}{c}101.81 \pm \\
1.79 \mathrm{c}, \mathrm{E}\end{array}$ & $\begin{array}{c}143.24 \pm \\
1.23^{\mathrm{d}, \mathrm{E}}\end{array}$ & $\underset{\mathrm{a}, \mathrm{E}}{31.93 \pm 0.44}$ & $\begin{array}{c}38.30 \pm 0.18 \\
\mathrm{~b}, \mathrm{E}\end{array}$ & $\underset{c, E}{69.66 \pm 0.12}$ & $\underset{\mathrm{d}, \mathrm{E}}{96.70 \pm 0.93}$ & $\underset{\mathrm{a}, \mathrm{E}}{21.43 \pm 0.39}$ & $\begin{array}{c}25.54 \pm 0 \\
\mathrm{~b}, \mathrm{E}\end{array}$ & $\underset{\mathrm{c}, \mathrm{E}}{45.44 \pm 0.85}$ & $\underset{\mathrm{d}, \mathrm{E}}{62.69}$ \\
\hline 35 & $\underset{\mathrm{a}, \mathrm{F}}{42.80 \pm 0.56}$ & $\begin{array}{c}53.52 \pm 1.85 \\
\mathrm{~b}, \mathrm{~F}\end{array}$ & $\underset{\mathrm{c}, \mathrm{F}}{99.52 \pm 1.64}$ & $\begin{array}{c}141.18 \pm \\
1.71 \mathrm{~d}, \mathrm{~F}\end{array}$ & $\underset{\mathrm{a}, \mathrm{F}}{28.61 \pm 0.31}$ & $\begin{array}{c}35.07 \pm 0.47 \\
\mathrm{~b}, \mathrm{~F}\end{array}$ & $\underset{\mathrm{c}, \mathrm{F}}{66.48 \pm 0.38}$ & $\underset{\mathrm{d}, \mathrm{F}}{93.86 \pm 4.29}$ & $\underset{\mathrm{a}, \mathrm{F}}{17.96 \pm 0.28}$ & $\begin{array}{c}20.56 \pm 1.23 \\
b, F\end{array}$ & $\underset{\mathrm{c}, \mathrm{F}}{40.19 \pm 0.06}$ & $\underset{\mathrm{d}, \mathrm{F}}{57.88} 0.80$ \\
\hline
\end{tabular}

a-d: Different small letters in the superscript in the same row denote differences at $5 \%$ between the fresh calafate juice and their cycles, according to the LSD test. A-F: Different capital letters in the superscript in the same column denote differences at 5\% in the sample during storage time, according to the LSD test. C1, C2 and C3 represents cycle 1, cycle 2 and cycle 3 , respectively. 
At day 0 , the TBC values significantly increased as the cycles progressed, with an increase of approximately 1.2, 2.0 and 2.7, 1.1, 1.9 and 2.5 and 1.1, 1.8 and 2.4 times in relation to the initial TBC value, for TPC, TAC and TFC, for cycle 1, cycle 2 and cycle 3, respectively. Various studies showed a similar upward trend for TBC in the cryconcentration of orange juice [10], maqui juice [14], strawberry juice [15], pineapple juice [16], apple juice [17,32], blueberry juice [38] and broccoli extract [54], i.e., since as liquid food was concentrated at low temperatures, the thermolabile components were highly protected in comparison to high thermal concentration technology as evaporation, which seriously affects the bioactive composition of the liquid food due to the high processing temperatures [6].

In the first week of storage, all the samples presented a significant increase in TBC values, which exceeded the initial TBC value between $4 \%$ to $11 \%$. This effect could be associated to the TSS behavior (Figure 1), since in the same week (day 7), the TSS values were higher than the initial results, and later, it decreased considerably during the weeks. Therefore, TSS and TBC are directly proportional. A clear and drastic decrease in TBC values was observed in the next weeks, and at the end of 35 days of storage, there was a reduction of up to $22 \%, 16 \%, 7 \%$ and $4 \%$ for TPC, $31 \%, 25 \%, 14 \%$ and $8 \%$ for TAC and $44 \%, 41 \%, 31 \%$ and $25 \%$ for TFC, with respect to the initial TBC value (day 0 ) for fresh juice, cycle one, cycle two and cycle three, respectively. This decline in the TBC values can be linked by factors as oxidation and/or polymerization of phenolic compounds with various proteins, and condensation of pigments with phenolic compounds present in the juice. Besides, the TBC degradation during storage time has been related to peroxidase enzyme activity [55]. However, to date, there are no studies on CC and enzymes that degrade bioactive components such as peroxidase, allowing the opening to future research.

\subsection{TAA of Fresh and Cryoconcentrated Samples}

The TAA values (mM TE in $100 \mathrm{~g}$, on dry matter) in the fresh juice were approximately 6.9, 14.7, 23.0 and 21.4 for DPPH, ABTS, FRAP and ORAC, respectively (Table 5). These values are in line with values reported by Ruiz et al. [1], Mariangel et al. [3] and Brito et al. [53], who studied the antioxidant activity of calafate from different harvest seasons and geographical areas in Southern Chile, indicating that the variation in TAA values could be due to specific climatic and agricultural environments, since each Region presents endless characteristics that affect the genetic and growth of the fruits, pre-harvest phases, ripening, post-harvest processing, among other conditions, and thus, all these conditions impacts on the composition of the fruit.

As in TSS and TPC, as the cycles advanced, the differences in TAA values were statistically significant between the fresh juice and each cycle, with an increase of 2.5, 3.9 and 5.2-fold, 2.6, 3.9 and 5.1-fold, 1.9, 2.9 and 4.0-fold and 3.0, 4.1 and 5.3-fold, in comparison to the initial TAA values (fresh juice, day 0), for cycle one, cycle two and cycle three, for DPPH, ABTS, FRAP and ORAC, respectively. This upward behavior indicates a direct relationship with TSS and TBC values, since both values increased as the cycles progressed. The results are in agreement with CC reports applied to different liquid foods $[15,48,56]$. Hence, our results confirm that the conditions used to concentrate calafate juice allows an increase of TAA values, and thus, the sensitive components, as total anthocyanin content, are preserved, and these contribute to a high TAA $[16,17,57,58]$.

As weeks passed, the TAA was progressively degraded, and at day 35 , the fresh calafate juice was the sample most affected by storage time, with a decrease close to $40 \%, 42 \%, 48 \%$ and $50 \%$, while, the third cycle gave lower TAA losses than the other samples, with reduction of approximately $15 \%, 19 \%$, $24 \%$ and $27 \%$ in relation to the fresh juice value (day 0), for DPPH, ABTS, FRAP and ORAC, respectively. The downward trend of TAA values during the storage for several weeks are in agreement with other studies on fruit juices, which have described continuous TAA degradation such as sugarcane juice [42], grape juice $[43,46]$, strawberry juice $[50,59]$ and orange juice [60], which indicate that the oxidation of bioactive compounds and polymerization reactions of anthocyanins could be linked to the loss of antioxidant activity as the days passed. 
Table 5. Total antioxidant activity (TAA) values of fresh calafate juice and cryoconcentrate samples during storage.

\begin{tabular}{|c|c|c|c|c|c|}
\hline Day & Sample & DPPH * & ABTS * & FRAP $* *$ & ORAC ** \\
\hline \multirow{4}{*}{0} & Fresh juice & $6.86 \pm 0.51^{a}$ & $14.74 \pm 2.73^{a}$ & $23.01 \pm 1.87^{\mathrm{a}}$ & $21.40 \pm 1.25^{\mathrm{a}}$ \\
\hline & C1 & $17.28 \pm 1.47^{b}$ & $38.91 \pm 3.23^{b}$ & $43.95 \pm 3.04^{b}$ & $63.77 \pm 3.79^{b}$ \\
\hline & $\mathrm{C} 2$ & $26.61 \pm 1.51^{\mathrm{c}}$ & $57.04 \pm 1.11^{\mathrm{c}}$ & $67.19 \pm 2.57^{c}$ & $87.95 \pm 1.22^{c}$ \\
\hline & $\mathrm{C} 3$ & $35.61 \pm 2.04^{d}$ & $75.47 \pm 7.34^{\mathrm{d}}$ & $93.19 \pm 5.74^{d}$ & $113.21 \pm 5.96^{d}$ \\
\hline \multirow{4}{*}{7} & Fresh juice & $7.11 \pm 0.91^{a}$ & $15.25 \pm 0.77^{a}$ & $23.91 \pm 2.12^{a}$ & $22.10 \pm 1.77^{a}$ \\
\hline & C1 & $18.36 \pm 1.30^{b}$ & $41.42 \pm 2.15^{b}$ & $46.64 \pm 1.41^{b}$ & $68.06 \pm 1.14^{b}$ \\
\hline & $\mathrm{C} 2$ & $28.95 \pm 1.74^{c}$ & $61.71 \pm 4.39^{c}$ & $72.51 \pm 5.01^{\mathrm{c}}$ & $95.20 \pm 2.65^{c}$ \\
\hline & $\mathrm{C} 3$ & $39.51 \pm 1.62^{d}$ & $82.92 \pm 2.55^{\mathrm{d}}$ & $102.23 \pm 5.39 \mathrm{~d}$ & $124.12 \pm 3.24^{d}$ \\
\hline \multirow{4}{*}{14} & Fresh juice & $6.12 \pm 0.25^{a}$ & $12.02 \pm 0.37^{\mathrm{a}}$ & $17.97 \pm 1.71^{\mathrm{a}}$ & $15.96 \pm 2.11^{\mathrm{a}}$ \\
\hline & C1 & $16.23 \pm 0.91^{b}$ & $35.41 \pm 1.84^{b}$ & $37.21 \pm 3.27^{b}$ & $52.18 \pm 4.16^{b}$ \\
\hline & $\mathrm{C} 2$ & $25.36 \pm 1.01^{c}$ & $53.62 \pm 2.41^{c}$ & $59.32 \pm 4.91^{c}$ & $74.63 \pm 2.54^{c}$ \\
\hline & C3 & $34.57 \pm 2.21^{\mathrm{d}}$ & $72.36 \pm 1.99 \mathrm{~d}$ & $85.70 \pm 3.22^{d}$ & $101.12 \pm 5.37^{d}$ \\
\hline \multirow{4}{*}{21} & Fresh juice & $5.33 \pm 0.33^{a}$ & $10.98 \pm 0.78^{a}$ & $16.34 \pm 1.41^{\mathrm{a}}$ & $14.42 \pm 1.24^{\mathrm{a}}$ \\
\hline & C1 & $15.08 \pm 1.41^{b}$ & $33.08 \pm 1.02^{b}$ & $35.28 \pm 4.34^{b}$ & $49.26 \pm 2.04^{b}$ \\
\hline & $\mathrm{C} 2$ & $24.24 \pm 1.07^{\mathrm{c}}$ & $50.99 \pm 2.01^{\mathrm{c}}$ & $56.76 \pm 3.80^{\mathrm{c}}$ & $71.88 \pm 1.95^{\mathrm{c}}$ \\
\hline & $\mathrm{C} 3$ & $33.41 \pm 2.57^{\mathrm{d}}$ & $69.15 \pm 2.07^{\mathrm{d}}$ & $83.43 \pm 4.51^{\mathrm{d}}$ & $97.95 \pm 3.35^{\mathrm{d}}$ \\
\hline \multirow{4}{*}{28} & Fresh juice & $4.69 \pm 0.40^{\mathrm{a}}$ & $9.81 \pm 0.81^{\mathrm{a}}$ & $13.80 \pm 1.71^{\mathrm{a}}$ & $12.36 \pm 1.23^{a}$ \\
\hline & C1 & $13.26 \pm 1.02^{b}$ & $29.14 \pm 2.17^{b}$ & $31.51 \pm 2.36^{b}$ & $42.99 \pm 3.04^{b}$ \\
\hline & $\mathrm{C} 2$ & $22.33 \pm 2.14^{\mathrm{c}}$ & $45.48 \pm 1.06^{\mathrm{c}}$ & $51.04 \pm 3.25^{c}$ & $62.45 \pm 2.06^{c}$ \\
\hline & $\mathrm{C} 3$ & $32.27 \pm 0.43^{\mathrm{d}}$ & $65.73 \pm 1.94{ }^{d}$ & $78.70 \pm 2.74^{\mathrm{d}}$ & $92.52 \pm 4.33^{\mathrm{d}}$ \\
\hline \multirow{4}{*}{35} & Fresh juice & $4.11 \pm 0.72^{\mathrm{a}}$ & $8.54 \pm 1.99^{a}$ & $12.04 \pm 1.95^{\mathrm{a}}$ & $10.69 \pm 2.54^{a}$ \\
\hline & C1 & $12.33 \pm 1.36^{b}$ & $26.25 \pm 0.77^{b}$ & $28.49 \pm 1.21^{b}$ & $37.85 \pm 1.74^{b}$ \\
\hline & $\mathrm{C} 2$ & $20.96 \pm 4.02^{c}$ & $42.11 \pm 1.67^{\mathrm{c}}$ & $45.38 \pm 2.85^{\mathrm{c}}$ & $57.12 \pm 3.23^{c}$ \\
\hline & $\mathrm{C} 3$ & $30.22 \pm 2.74 \mathrm{~d}$ & $60.96 \pm 7.25^{\mathrm{d}}$ & $71.18 \pm 4.14^{\mathrm{d}}$ & $82.16 \pm 4.47^{\mathrm{d}}$ \\
\hline
\end{tabular}

Different letters in the same column show significant differences at $5 \%$ between homogeneous groups in each variable to a LSD. C1, C2 and C3 represents cycle 1, cycle 2 and cycle 3, respectively. * Free radical scavenging capacity and ${ }^{* *}$ Ferric reducing antioxidant power. All were determined as (mM TE/g d.m.)

\subsection{Correlation between $T B C$ and $T A A$}

Correlation coefficients between TBC and TAA for cycle three are shown in Table 6. Furthermore, the correlation coefficients for fruit juice, cycle one and cycle two are presented in the Supplementary Materials (Tables S1-S3).

Table 6. Pearson's correlation coefficients (r) between biological active compounds content (TBC and TAA) obtained by centrifugal block cryoconcentration (CBCC) process (third cycle).

\begin{tabular}{cccccccc}
\hline & TPC & TAC & TFC & DPPH & ABTS & FRAP & ORAC \\
\hline TPC & 1.00 & & & & & & \\
TAC & $0.97 *$ & 1.00 & & & & & \\
TFC & $0.96 *$ & $0.96 *$ & 1.00 & & & & \\
DPPH & $0.94 *$ & $0.99 *$ & $0.98^{*}$ & 1.00 & & & \\
ABTS & $0.90 *$ & $0.98^{*}$ & $0.99 *$ & $1.00 *$ & 1.00 & & \\
FRAP & $0.91 *$ & $0.97 *$ & $0.98^{*}$ & $0.99 *$ & $1.00 *$ & 1.00 & \\
ORAC & $0.90 *$ & $0.96 *$ & $0.97 *$ & $0.98 *$ & $0.99 *$ & $1.00 *$ & 1.00 \\
\hline \multicolumn{7}{c}{$*$ Significant at $5 \%}$.
\end{tabular}

In all the samples, a positive and significant correlation was found between the biological active compounds content. The values ( $\mathrm{r}$ ) between 0.9 to 1.0, indicating the direct and proportional results between TBC and TAA, i.e., each component increased or decreased, as the cycles or the days under storage progressed, respectively. A similar trend was distinguished by Casas-Forero et al. [38] and 
Correa et al. [57], who reported a high correlation ( 0.9 to 1.0) between antioxidant activity and bioactive compound in CC applied to blueberry juice and aqueous coffee extract, respectively.

\subsection{Sensorial Analysis}

The acceptance scores attributed by the panelists between fresh calafate juice and reconstituted cryoconcentrated juice (third cycle) are represented in Figure 3.

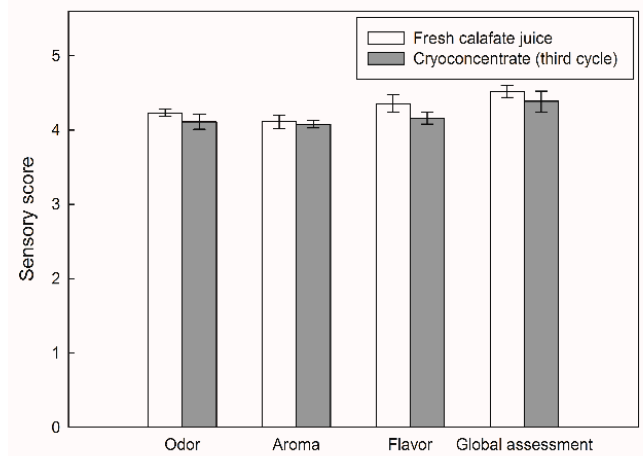

(a)

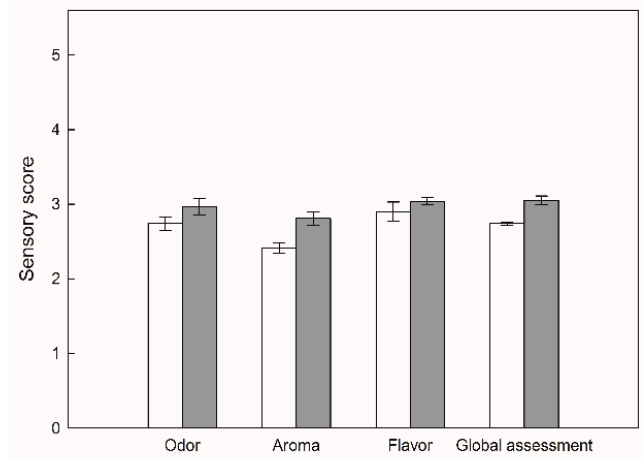

(c)

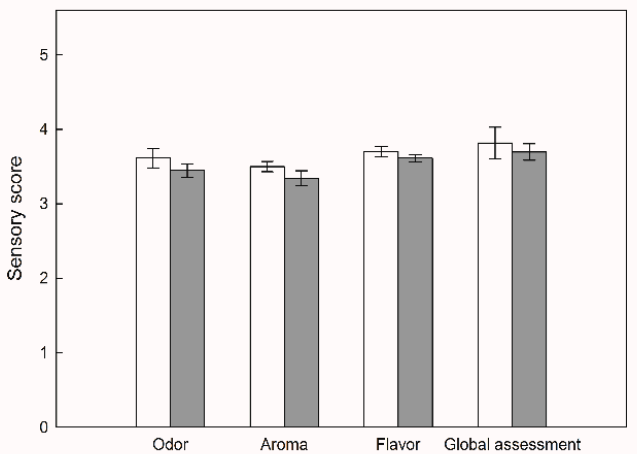

(b)

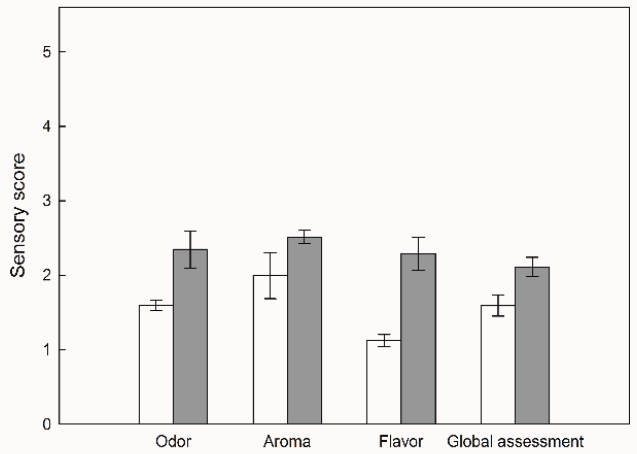

(d)

Figure 3. Sensory attributes between fresh calafate juice and reconstituted cryoconcentrated sample at the third cycle: (a) day 0; (b) day 7; (c) day 14; and (d) day 21.

In relation to the day 0 , there were no significant differences in odor, aroma, flavor and global assessment between the fresh juice and reconstituted cryoconcentrated sample. Specifically, all the values were assessed as "like", since the evaluations were superior to four points, i.e., the panelists specified a pleasure when tasting the fresh and cryoconcentrated juices, without finding differences when comparing the quality sensorial characteristics.

At day 7, the hedonic scale scores decreased significantly compared at day 0 , with values between 3.0 and 3.8 points, which is equivalent to the category "liked slightly". Therefore, the samples were considered as accepted for the sensorial panelists. Despite the decline, there were no statistical differences between the scores assigned by the panelists for the sensory attributes among the samples.

Nonetheless, as days advanced, the panelists reported an increase in the degree of rejection between samples, since the scores decreased considerably, and in addition, the points between the fresh juice and cryoconcentrated varied significantly. Specifically, the cryoconcentrated had better acceptance than the fresh juice, with scores of approximately $2.8-3.0$ versus $2.4-2.9$ and $2.1-2.5$ versus $1.1-2.0$, for day 14 and day 21, respectively. Thus, these scores designated a negative impression of the samples with respect to their sensorial characteristics. However, from 14 days in storage, the cryoconcentrates were more accepted to the sensory panel than the fresh juice, reinforcing that CC maintains better sensory attributes in the reconstituted concentrates than fresh juice during refrigerated storage. 
Based on these results, at day 14 and day 21, the cryoconcentrated samples presented better scores than the fresh juice, since, as mentioned above, previous studies have shown that CC technology allowed the obtaining of high TSS values, and in turn, these increases the volatile compounds release [17]. Therefore, the reconstituted juice contains a high organoleptic acceptance that can be connected to taste and aroma, and thus, it resist storage time better than fresh juice, since the fresh juice possibly had a high fermentation level, generating more rancid odors and flavors on day 21 [61], i.e., the fresh juice was more vulnerable to external factors [62], which eventually led to a high degree of rejection. However, to date, there are no studies that compare a fruit juice with a reconstituted cryoconcentrated juice in terms of bioactive components, antioxidant capacity, volatile compounds and physicochemical properties. Therefore, a very interesting study about the commercialization of cryoconcentrated juice could be realized with similar concentration that a fresh juice.

Sensory analysis results on days 28 and 35 were not presented, since on day 21, the panelists indicated a high disgust and complete rejection, with values less than 2.5 point for all the characteristics evaluated.

Therefore, CC technology allows the preservation of different sensory attributes, and in turn, its concentration at low temperatures proves a high similarity in the reconstituted concentrate to the original sample. Analogous trends were observed in CC studies applied to apple juice [17], coffee extract [31], black currant juice [63] and Andes berry pulp [64].

\section{Conclusions}

CBCC positively affects the quality properties of fresh calafate juice, as exemplified by the high TSS values obtained in the last cycle $\left(42^{\circ}\right.$ Brix). Additionally, this non-thermal technology intensifies the natural juice color to an attractive dark reddish color. Subjecting fresh calafate juice to CBCC resulted in high TBC content, with values over 2.4 times the initial TBC values. Moreover, the TAA presented a similar behavior, since these increased between 4.0 to 5.3 times, in comparison to the initial TAA values. These values indicate the advantages of CBCC application as a green technology to extract a high amount of concentrated liquid from the ice matrix without the use of high temperatures.

Under refrigerated storage time of 35 days, the CBCC samples showed better stability than the fresh juice, since the cryoconcentrated samples showed a low decreasing rate in their nutritional properties, inferring that $\mathrm{CBCC}$ allows to concentrate and to retain various bioactive and antioxidant components naturally present in calafate juice.

Additionally, until the day 21, sensory panelists reported acceptability of the reconstituted cryoconcentrated sample, while the fresh juice was totally rejected, reinforcing that CBCC also concentrate and preserve volatile components that are perceived by the panelists as an important quality parameter.

Therefore, CBCC can be considered a novel and viable technology for the preservation of quality attributes from fresh native juice with interesting food application of the cryoconcentrates due to its high stability during storage time and low bioactive components degradation in comparison to the fresh juice.

Supplementary Materials: The following are available online at http://www.mdpi.com/2304-8158/9/9/1314/s1, Figure S1: Visual appearance of fresh juice and concentrate samples at each cycle during storage., Table S1: Pearson's correlation coefficients (r) between biological active compounds content of fresh calafate juice., Table S2: Pearson's correlation coefficients ( $\mathrm{r}$ ) between biological active compounds content (TBC and TAA) obtained by CBCC process (first cycle), Table S3: Pearson's correlation coefficients (r) between biological active compounds content (TBC and TAA) obtained by CBCC process (second cycle).

Author Contributions: Conceptualization, P.O.-P., R.N.Z. and G.P.; methodology, P.O.-P., N.C.-F. and G.T.-B.; software, G.T.-B. and N.C.-F.; validation, G.T.-B., R.N.Z. and N.C.-F.; formal analysis, P.O.-P. and G.T.-B.; investigation, P.O.-P., N.C.-F. and G.P.; resources, P.O.-P.; data curation, P.O.-P., G.T.-B., N.C.-F. and G.P.; writing—original draft preparation, P.O.-P. and R.N.Z.; writing—review and editing, P.O.-P. and G.P.; visualization, P.O.-P.; supervision, R.N.Z. and G.P.; project administration, P.O.-P.; funding acquisition, P.O.-P. All authors have read and agreed to the published version of the manuscript. 
Funding: This research was funded by ANID-Chile (Agencia Nacional de Investigación y Desarrollo de Chile) through the FONDECYT Postdoctoral Grant 2019 (Folio 3190420).

Acknowledgments: Patricio Orellana-Palma acknowledges the financial support of ANID-Chile (Agencia Nacional de Investigación y Desarrollo de Chile) through the FONDECYT Postdoctoral Grant 2019 (Folio 3190420).

Conflicts of Interest: The authors declare no conflict of interest.

\section{References}

1. Ruiz, A.; Hermosin-Gutierrez, I.; Mardones, C.; Vergara, C.; Herlitz, E.; Vega, M.; Dorau, C.; Winterhalter, P.; von Baer, D. Polyphenols and antioxidant activity of calafate (Berberis microphylla) fruits and other native berries from Southern Chile. J. Agric. Food Chem. 2010, 58, 6081-6089. [CrossRef]

2. Schmeda-Hirschmann, G.; Jiménez-Aspee, F.; Theoduloz, C.; Ladio, A. Patagonian berries as native food and medicine. J. Ethnopharmacol. 2019, 241, 111979. [CrossRef] [PubMed]

3. Mariangel, E.; Reyes-Diaz, M.; Lobos, W.; Bensch, E.; Schalchli, H.; Ibarra, P. The antioxidant properties of calafate (Berberis microphylla) fruits from four different locations in southern Chile. Cien. Investig. Agrar. 2013, 40, 161-170. [CrossRef]

4. Sadilova, E.; Stintzing, F.C.; Kammerer, D.R.; Carle, R. Matrix dependent impact of sugar and ascorbic acid addition on color and anthocyanin stability of black carrot, elderberry and strawberry single strength and from concentrate juices upon thermal treatment. Food Res. Int. 2009, 42, 1023-1033. [CrossRef]

5. Hernández-Hernández, H.M.; Moreno-Vilet, L.; Villanueva-Rodríguez, S.J. Current status of emerging food processing technologies in Latin America: Novel non-thermal processing. Innov. Food Sci. Emerg. 2019, 58, 102233. [CrossRef]

6. Petzold, G.; Orellana, P.; Moreno, J.; Junod, J.; Bugueño, G. Freeze concentration as a technique to protect valuable heat-labile components of foods. In Innovative Processing Technologies for Foods with Bioactive Compounds, 1st ed.; Moreno, J.J., Ed.; CRC Press: Boca Raton, FL, USA, 2016; pp. 184-190.

7. Orellana-Palma, P.A. External Forces Assisted Cryoconcentration to Improve the Concentration Process and the Quality of Fruit Juices. Ph.D. Thesis, Universidad del Bío-Bío, Chillán, Chile, May 2018.

8. Amran, N.A.; Samsuri, S.; Safiei, N.Z.; Zakaria, Z.Y.; Jusoh, M. Review: Parametric study on the performance of progressive cryoconcentration system. Chem. Eng. Commun. 2016, 203, 957-975. [CrossRef]

9. Aider, M.; de Halleux, D. Passive and microwave-assisted thawing in maple sap cryoconcentration technology. J. Food Eng. 2008, 85, 65-72. [CrossRef]

10. Orellana-Palma, P.; Petzold, G.; Andana, I.; Torres, N.; Cuevas, C. Retention of ascorbic acid and solid concentration via centrifugal freeze concentration of orange juice. J. Food Qual. 2017, 2017, 5214909. [CrossRef]

11. Petzold, G.; Orellana, P.; Moreno, J.; Cerda, E.; Parra, P. Vacuum-assisted block freeze concentration applied to wine. Innov. Food Sci. Emerg. 2016, 36, 330-335. [CrossRef]

12. Kawasaki, K.; Matsuda, A.; Kadota, H. Freeze concentration of equal molarity solutions with ultrasonic irradiation under constant freezing rate; effect of solute. Chem. Eng. Res. Des. 2006, 84, 107-112. [CrossRef]

13. Petzold, G.; Aguilera, J.M. Centrifugal freeze concentration. Innov. Food Sci. Emerg. 2013, 20, $253-258$. [CrossRef]

14. Bastías-Montes, J.M.; Martín, V.S.; Muñoz-Fariña, O.; Petzold-Maldonado, G.; Quevedo-León, R.; Wang, H.; Yang, Y.; Céspedes-Acuña, C.L. Cryoconcentration procedure for aqueous extracts of maqui fruits prepared by centrifugation and filtration from fruits harvested in different years from the same localities. J. Berry Res. 2019, 9, 377-394. [CrossRef]

15. Adorno, W.T.; Rezzadori, K.; Arend, G.D.; Chaves, V.C.; Reginatto, F.H.; Di Luccio, M.; Petrus, J.C. Enhancement of phenolic compounds content and antioxidant activity of strawberry (Fragaria $\times a n a n a s s a)$ juice by block freeze concentration technology. Int. J. Food Sci. Technol. 2017, 52, 781-787. [CrossRef]

16. Orellana-Palma, P.; Zuñiga, R.N.; Takhar, P.S.; Gianelli, M.P.; Petzold, G. Effects of centrifugal block freeze crystallization on quality properties in pineapple juice. Chem. Eng. Technol. 2020, 43, 355-364. [CrossRef]

17. Orellana-Palma, P.; Lazo-Mercado, V.; Gianelli, M.P.; Hernández, E.; Zuñiga, R.; Petzold, G. Influence of cryoconcentration on quality attributes of apple juice (Malus domestica cv. Red Fuji). Appl. Sci. 2020, 10, 959. [CrossRef]

18. Orellana-Palma, P.; Petzold, G.; Guerra-Valle, M.; Astudillo-Lagos, M. Impact of block cryoconcentration on polyphenol retention in blueberry juice. Food Biosci. 2017, 20, 149-158. [CrossRef] 
19. AOAC. Official Methods of Analysis of the Association of Official Analytical Chemists (AOAC) International, 19th ed.; Helrich, K., Ed.; AOAC: Washington, DC, USA, 1990; pp. 910-928.

20. Currie, L.A.; Svehla, G.Y.U.L.A. Nomenclature for the presentation of results of chemical analysis (IUPAC Recommendations 1994). Pure Appl. Chem. 1994, 66, 595-608. [CrossRef]

21. Singleton, V.L.; Orthofer, R.; Lamuela-Raventós, R.M. Analysis of total phenols and other oxidation substrates and antioxidants by means of Folin-ciocalteu reagent. Methods Enzymol. 1999, 29, 152-178. [CrossRef]

22. Lee, J.; Durst, R.W.; Wrolstad, R.E. Determination of total monomeric anthocyanin pigment content of fruit juices, beverages, natural colorants, and wines by the $\mathrm{pH}$ differential method: Collaborative study. J. AOAC Int. 2005, 88, 1269-1278. [CrossRef]

23. Dewanto, V.; Wu, X.; Adom, K.K.; Liu, R.H. Thermal processing enhances the nutritional value of tomatoes by increasing total antioxidant activity. J. Agric. Food Chem. 2002, 50, 3010-3014. [CrossRef]

24. Brand-Williams, W.; Cuvelier, M.E.; Berset, C. Use of a free radical method to evaluate antioxidant activity. LWT-Food Sci. Technol. 1995, 28, 25-30. [CrossRef]

25. Re, R.; Pellegrini, N.; Proteggente, A.; Pannala, A.; Yang, M.; Rice, C. Antioxidant activity applying an improved ABTS radical cation decolorization assay. Free Radic. Biol. Med. 1999, 26, 1231-1237. [CrossRef]

26. Benzie, I.F.F.; Strain, J.J. The ferric reducing ability of plasma (FRAP) as a measure of "Antioxidant Power": The FRAP assay. Anal. Biochem. 1996, 239, 70-76. [CrossRef] [PubMed]

27. Ou, B.; Hampsch, M.; Prior, R.L. Development and validation of an improved oxygen radical absorbance capacity assay using fluorescein as the fluorescent probe. J. Agric. Food Chem. 2001, 49, 4619-4626. [CrossRef]

28. Petzold, G.; Orellana, P.; Moreno, J.; Valeria, P. Physicochemical properties of cryoconcentrated orange juice. Chem. Eng. Trans. 2019, 75, 37-42. [CrossRef]

29. ODEPA. Catastro Frutícola Principales Resultados, Región de Los Lagos, Información Regional, Ministerio de Agricultura, Gobierno de Chile, Chile, 2019. Available online: https://www.odepa.gob.cl/wp-content/uploads/ 2019/09/catastro_aysen.pdf (accessed on 12 July 2020).

30. Petzold, G.; Moreno, J.; Lastra, P.; Rojas, K.; Orellana, P. Block freeze concentration assisted by centrifugation applied to blueberry and pineapple juices. Innov. Food Sci. Emerg. 2015, 30, 192-197. [CrossRef]

31. Moreno, F.L.; Quintanilla-Carvajal, M.X.; Sotelo, L.I.; Osorio, C.; Raventós, M.; Hernández, E.; Ruiz, Y. Volatile compounds, sensory quality and ice morphology in falling-film and block freeze concentration of coffee extract. J. Food Eng. 2015, 166, 64-71. [CrossRef]

32. Ding, Z.; Qin, F.G.; Yuan, J.; Huang, S.; Jiang, R.; Shao, Y. Concentration of apple juice with an intelligent freeze concentrator. J. Food Eng. 2019, 256, 61-72. [CrossRef]

33. Lemos, A.T.; Ribeiro, A.C.; Delgadillo, I.; Saraiva, J.A. Shelf-life extension of watermelon juice preserved by hyperbaric storage at room temperature compared to refrigeration. LWT-Food Sci. Technol. 2020, 117, 108695. [CrossRef]

34. Wahia, H.; Zhou, C.; Mustapha, A.T.; Amanor-Atiemoh, R.; Mo, L.; Fakayode, O.A.; Ma, H. Storage effects on the quality quartet of orange juice submitted to moderate thermosonication: Predictive modeling and odor fingerprinting approach. Ultrason. Sonochem. 2020, 64, 104982. [CrossRef]

35. Chia, S.L.; Rosnah, S.; Noranizan, M.A.; Ramli, W.W. The effect of storage on the quality attributes of ultraviolet-irradiated and thermally pasteurised pineapple juices. Int. Food Res. J. 2012, 19, 1001-1010.

36. Arena, M.E.; Zuleta, A.; Dyner, L.; Constenla, D.; Ceci, L.; Curvetto, N. Berberis buxifolia fruit growth and ripening: Evolution in carbohydrate and organic acid contents. Sci. Hortic. 2013, 158, 52-58. [CrossRef]

37. Khajehei, F.; Niakousari, M.; Eskandari, M.H.; Sarshar, M. Production of pomegranate juice concentrate by complete block cryoconcentration process. J. Food Process. Preserv. 2015, 38, 488-498. [CrossRef]

38. Casas-Forero, N.; Orellana-Palma, P.; Petzold, G. Influence of block freeze concentration and evaporation on physicochemical properties, bioactive compounds and antioxidant activity in blueberry juice. Food Sci. Technol. 2020, in press. [CrossRef]

39. Abid, M.; Jabbar, S.; Wu, T.; Hashim, M.M.; Hu, B.; Saeeduddin, M.; Zeng, X. Qualitative assessment of sonicated apple juice during storage. J. Food Process. Preserv. 2015, 39, 1299-1308. [CrossRef]

40. Bhardwaj, R.L.; Pandey, S. Juice blends-a way of utilization of under-utilized fruits, vegetables, and spices: A review. Crit. Rev. Food Sci. Nutr. 2011, 51, 563-570. [CrossRef]

41. Parish, M.E.; Worobo, R.W.; Danyluk, M.D. Juices and Juice-containing Beverages. In Compendium of Methods for the Microbiological Examination of Foods, 1st ed.; Salfinger, Y., Tortorello, M.L., Eds.; Apha Press: Philadelphia, PA, USA, 2015; pp. 115-156. 
42. Zia, S.; Khan, M.R.; Zeng, X.A.; Shabbir, M.A.; Aadil, R.M. Combined effect of microwave and ultrasonication treatments on the quality and stability of sugarcane juice during cold storage. Int. J. Food Sci. Technol. 2019, 54, 2563-2569. [CrossRef]

43. Mesquita, T.C.; Schiassi, M.C.E.V.; Lago, A.M.T.; Careli-Gondim, Í.; Silva, L.M.; de Azevedo Lira, N.; Nunes Carvalho, E.E.; de Oliveira Lima, L.C. Grape juice blends treated with gamma irradiation evaluated during storage. Radiat. Phys. Chem. 2020, 168, 108570. [CrossRef]

44. Mezey, J.; Mezeyová, I. Changes in the levels of selected organic acids and sugars in apple juice after cold storage. Czech J. Food Sci. 2018, 36, 175-180. [CrossRef]

45. Orellana-Palma, P.; González, Y.; Petzold, G. Improvement of centrifugal cryoconcentration by ice recovery applied to orange juice. Chem. Eng. Technol. 2019, 42, 925-931. [CrossRef]

46. Igual, M.; Contreras, C.; Camacho, M.M.; Martínez-Navarrete, N. Effect of thermal treatment and storage conditions on the physical and sensory properties of grapefruit juice. Food Bioprocess Technol. 2014, 7, 191-203. [CrossRef]

47. Cano-Lamadrid, M.; Nowicka, P.; Hernández, F.; Carbonell-Barrachina, A.A.; Wojdyło, A. Phytochemical composition of smoothies combining pomegranate juice (Punica granatum $\mathrm{L}$ ) and Mediterranean minor crop purées (Ficus carica, Cydonia oblonga, and Ziziphus jujube). J. Sci. Food Agric. 2018, 98, 5731-5741. [CrossRef] [PubMed]

48. Zielinski, A.A.; Zardo, D.M.; Alberti, A.; Bortolini, D.G.; Benvenutti, L.; Demiate, I.M.; Nogueira, A. Effect of cryoconcentration process on phenolic compounds and antioxidant activity in apple juice. J. Sci. Food Agric. 2019, 99, 2786-2792. [CrossRef] [PubMed]

49. Qin, F.G.; Ding, Z.; Peng, K.; Yuan, J.; Huang, S.; Jiang, R.; Shao, Y. Freeze concentration of apple juice followed by centrifugation of ice packed bed. J. Food Eng. 2020, 291, 110270. [CrossRef]

50. Yildiz, G.; Aadil, R.M. Comparison of high temperature-short time and sonication on selected parameters of strawberry juice during room temperature storage. Int. J. Food Sci. Technol. 2020, 57, 1462-1468. [CrossRef]

51. Wurlitzer, N.J.; Dionísio, A.P.; Lima, J.R.; dos Santos Garruti, D.; da Silva Araújo, I.M.; da Rocha, R.F.J.; Maia, J.L. Tropical fruit juice: Effect of thermal treatment and storage time on sensory and functional properties. J. Food Sci. Technol. 2019, 56, 5184-5193. [CrossRef]

52. Pankaj, B.P.; Umezuruike, L.O.; Fahad, A.A. Colour measurement and analysis in fresh and processed foods: A review. Food Bioprocess Technol. 2013, 6, 36-60. [CrossRef]

53. Brito, A.; Areche, C.; Sepúlveda, B.; Kennelly, E.J.; Simirgiotis, M.J. Anthocyanin characterization, total phenolic quantification and antioxidant features of some Chilean edible berry extracts. Molecules 2014, 19, 10936-10955. [CrossRef]

54. Azhar, A.N.; Panirselvam, M.; Amran, N.A.; Ruslan, M.S.; Samsuri, S. Retention of total phenolic content and antioxidant activity in the concentration of broccoli extract by progressive freeze concentration. Int. J. Food Eng. 2020, in press. [CrossRef]

55. Feng, X.; Zhou, Z.; Wang, X.; Bi, X.; Ma, Y.; Xing, Y. Comparison of high hydrostatic pressure, ultrasound, and heat treatments on the quality of strawberry-apple-lemon juice blend. Foods 2020, 9, 218. [CrossRef]

56. Samsuri, S.; Li, T.H.; Ruslan, M.S.H.; Amran, N.A. Antioxidant recovery from pomegranate peel waste by integrating maceration and freeze concentration technology. Int. J. Food Eng. 2020. in Press. [CrossRef]

57. Correa, L.J.; Ruiz, R.Y.; Moreno, F.L. Effect of falling-film freeze concentration on bioactive compounds in aqueous coffee extract. J. Food Process Eng. 2018, 41, e12606. [CrossRef]

58. Orellana-Palma, P.; Petzold, G.; Pierre, L.; Pensaben, J.M. Protection of polyphenols in blueberry juice by vacuum-assisted block freeze concentration. Food Chem. Toxicol. 2017, 109, 1093-1102. [CrossRef]

59. Tomadoni, B.; Cassani, L.; Viacava, G.; Moreira, M.D.R.; Ponce, A. Effect of ultrasound and storage time on quality attributes of strawberry juice. J. Food Process Eng. 2017, 40, e12533. [CrossRef]

60. Lu, Q.; Li, L.; Xue, S.; Yang, D.; Wang, S. Stability of flavonoid, carotenoid, soluble sugar and vitamin C in 'Cara Cara' juice during storage. Foods 2019, 8, 417. [CrossRef]

61. Rios-Corripio, G.; Guerrero-Beltrán, J.A. Physicochemical, antioxidant and sensory characteristics of black cherry (Prunus serotina subsp. capuli) fermented juice. Int. J. Fruit Sci. 2020, in press. [CrossRef]

62. Walkling-Ribeiro, M.; Noci, F.; Cronin, D.A.; Lyng, J.G.; Morgan, D.J. Shelf life and sensory evaluation of orange juice after exposure to thermosonication and pulsed electric fields. Food Bioprod. Process. 2009, 87, 102-107. [CrossRef] 
63. Dette, S.S.; Jansen, H. Freeze concentration of black currant juice. Chem. Eng. Technol. 2010, 33, 762-766. [CrossRef]

64. Ramos, F.A.; Delgado, J.L.; Bautista, E.; Morales, A.L.; Duque, C. Changes in volatiles with the application of progressive freeze-concentration to Andes berry (Rubus glaucus Benth). J. Food Eng. 2005, 69, 291-297. [CrossRef] 